\title{
Synthesis of $\mathrm{Li}\left[\mathrm{Li}_{0.2} \mathrm{Mn}_{0.54} \mathrm{Ni}_{0.13} \mathrm{Co}_{0.13}\right] \mathrm{O}_{2}$ Cathode Material in Acetate System for Lithium-Ion Battery
}

\author{
Zhongcai Shao, Lina Yv ,Jinbo Hu, Yongxin Zhao, Shihang Dai \\ School of Environmental and Chemical Engineering, Shenyang Ligong University \\ *E-mail: 1804396614@qq.com
}

doi: $10.20964 / 2018.03 .08$

Received: 22 June 2017 / Accepted: 25 September 2017 / Published: 5 February 2018

This paper adopted the co-precipitation method with acetate as raw material to prepare $\mathrm{Li}\left[\mathrm{Li}_{0.2} \mathrm{Mn}_{0.54} \mathrm{Ni}_{0.13} \mathrm{Co}_{0.13}\right] \mathrm{O}_{2}$ in acetic acid system, which was analyzed by XRD, SEM and electrochemical testing methods, studying the performance of the cathode material under different calcining temperature and calcine time. The results showed that the optimum calcines temperature and time of the sample were respectively $800^{\circ} \mathrm{Cand} 8 \mathrm{~h}$; under the optimal calcine temperature and time, the first charge and discharge capacity was $161.788 \mathrm{mAh} / \mathrm{g}$ and the discharge specific capacity was $92.242 \mathrm{mAh} / \mathrm{g}$ at $0.1 \mathrm{C}$ rate; after the 20 times cycle test, the charge and discharge efficiency of materials can be over $95 \%$.

Keywords: Lithium-ion battery; Acetate system; Anode material ; Calcine temperature; Calcine time

\section{FULL TEXT}

(C) 2018 The Authors. Published by ESG (www.electrochemsci.org). This article is an open access article distributed under the terms and conditions of the Creative Commons Attribution license (http://creativecommons.org/licenses/by/4.0/). 